\title{
Physicochemical Analysis of Pomegranate of Gilgit Baltistan, Pakistan
}

\author{
Faisal Abbas ${ }^{1}$, Nawazish Ali ${ }^{1}$, Yawar Abbas ${ }^{2}$, Attarad Ali ${ }^{3}$, Naveed Hussain ${ }^{1}$, Tanveer Abbas ${ }^{1}$, \\ Abdul-Rehman Phull ${ }^{4}$, Islamuddin ${ }^{5}$ \\ ${ }^{1}$ Department of Agriculture and Food Technology, Karakoram International University, Gilgit, Pakistan \\ ${ }^{2}$ Department of Earth \& Environmental Sciences, Bahria University, Islamabad, Pakistan \\ ${ }^{3}$ Department of Biotechnology, Quid-i-Azam University, Islamabad, Pakistan \\ ${ }^{4}$ Department of Biology, Kongju National University, Gongju, Republic of Korea \\ ${ }^{5}$ Rescue 1122 Gilgit, Pakistan
}

\section{Email address:}

abbas.qasimi@gmail.com (F. Abbas),amjadmalik747@gmail.com (N. Ali),yawar_zaid@yahoo.com (Y. Abbas), attarad.ali@kiu.edu.pk (A. Ali),naveed_kiu@yahoo.com (N. Hussain), abbasglt110@gmail.com (T. Abbas), ab.rehman174@gmail.com (Abdul-Rehman P.), sanil_110@yahoo.com(Islamuddin)

\section{To cite this article:}

Faisal Abbas, Nawazish Ali, Yawar Abbas, Attarad Ali, Naveed Hussain, Tanveer Abbas, Abdul-Rehman Phull, Islamuddin. Physicochemical Analysis of Pomegranate of Gilgit Baltistan, Pakistan. Agriculture, Forestry and Fisheries. Vol. 4, No. 6, 2015, pp. $246-251$.

doi: $10.11648 /$ j.aff.20150406.12

\begin{abstract}
Juice can be considered as an important and functional ingredient in food products. The aim of current study was to screen and compare the physico-chemical properties of some indigenous species of pomegranate in Gilgit-Baltistan (GB) Pakistan. Fruits were collected from three tehsil regions of GB i.e. Bagrote, Jalalabad and Heramosh valleys. The fruits were washed, peeled off and arils were separated. Fresh juice was prepared from the arils and physico-chemical properties were evaluated. The $\mathrm{pH}$ of juice was found in the range of 2.4 (Sour, Jutial Gilgit) to 3.9 (sweet, Jalalabad). Comparative to other areas, pomegranate species of the Jutial exhibited higher total soluble solids (TSS) as 11.5 (sour) 14.5 (sweet) 14.2 (doom). The proximate reducing sugar analysis showed the higher content of reducing sugars in Sweet $>$ Doom $>$ Sour varieties. Lowest average ash and moisture content was observed in sour and higher was determined in sweet varieties.
\end{abstract}

Keywords: Physico-Chemical, Gilgit-Baltistan (GB), Pomegranate, Nutrients, Juice, Tehsil, TSS

\section{Introduction}

Pomegranate (Punicagranatum L.) belongs to the Punicacea family (Hardeet al., 1970). It is one of the important and commercial horticultural fruits which is generally very well adapted to the Mediterranean climate (Biale, 1981). It has been cultivated extensively in Iran, India and some parts in the U.S.A (California), China, Japan and Russia. Pomegranate fruits are consumed fresh or processed as juice, jellies and syrup for industrial production (Hodgson, 1917). Different parts of its tree (leaves, fruits and barks) have been used traditionally for their medicinal properties and for other purposes such as in tanning (Rania and $\mathrm{Ne}^{\prime} \mathrm{jib}$, 2007).

Historical evidence reveals that its primary origin is in Iran where it has been grown in every area, both coastal and mountainous areas. It has now been spread to all other regions of the world (Kumar, 1990). Turkey was analyzed for the chemical components, some of which was found for nutritional and health. Four samples were found to contain glucose syrup one of which was found to have very high amount of hydroxymethylfurfural $(152498 \mathrm{mg} / \mathrm{kg})$. Twelve pomegranate (Punica granatum L.) cultivars obtained from different growing regions of Iran were analyzed for their physical and chemical properties. These properties included fruit fresh weight, volume and density, peel thickness, soluble solids (TSS), titratable acidity (TA), EC, pH, vitamin C, ellagic acid content of juice and peel, total antioxidant activity of peel and juice and etc. Fruit weight ranged from 103.38 to $505.00 \mathrm{~g}$ and fruit volume from 99.41 to $547.88 \mathrm{~cm}$. Similarly, average fruit density ranged 0.91 g.cm G3 to 1.04 g.cm G3 and peel thickness of the fruit was recorded from 1.60 to $6.01 \mathrm{~mm}$. Reducing sugars (Vahid et al., 2009).

Different parts of its tree (leaves, fruits and bark skin) have 
been used traditionally for their medicinal properties and for other purposes such as in tanning (Rania et al., 2007). The edible part of the fruit contains considerable amounts of acids, sugars, vitamins, polysaccharides, polyphenols and important minerals. (Gil, et al.,2000). The pomegranate fruit is widely considered as a "healthy" fruit due to its biological actions, most of them attributed to its phenolic content (Lansky and Newman, 2007). Studies about pomegranate polyphenols have shown prevention of cardiovascular, cancer diseases and neurological damage in humans (Aviram et al., 2002).

\section{Materials and Methods}

\subsection{Study Area}

The present study was conducted in the Department of Agriculture and Food Technology, Karakorum International University Gilgit. The present study was carried out during 2010 growing season pomegranate trees grown in different areas of three districts of Gilgit Baltistan. All treatments were carried out in first week of September to last week of October.

\subsection{Collection of Sample}

Thirty normal size pomegranates were obtained from mature fruits growing in Bagrote, Jalal Abad and Heramoshvallies of district Gilgit. Commercially ripe fresh fruits were harvested during September and October from different mature trees randomly selected to represent the population of the plantation. The fruits was harvested at commercially maturity stage and transported to the Food Technology Laboratory of Karakorum International University Gilgit.

\subsection{Separation of Seeds}

Fruits were cleaned and washed to remove all foreign matters such as dust, then peeling was done manually by knife and grains or aerials were separated by hands.

\subsection{Juice Extraction and Filtration}

The pulp was extracted from the seeds of pomegranate varieties. Electric blender of good quality was used to crush seeds. Extracted juice was filtered by means of muslin cloths to separate juice from the pulp, fiber and seed particles.

\subsection{Analysis of Physico Chemical Parameters of Pomegranate Juice}

Following chemical parameters of juice of different pomegranate varieties was measured.

PH:

The $\mathrm{pH}$ values of samples were measured by using $\mathrm{pH}$ meter (Inolab) according to AOAC (1990) method No.981-12.

Principle:

The basic principle of electrometric $\mathrm{pH}$ meter is determination of the activity of hydrogen ions by potentiometer measurement using a standard hydrogen electrode and reference electrode. The glass electrode is commonly used. The $\mathrm{pH}$ value of an aqueous solution is defined by the equation:

$$
\mathrm{pH}=-\log 10 \mathrm{AH}+
$$

Where, $\mathrm{AH}+=$ the activity of hydrogen ions in the solution in g-moles/l. The electromotive force (emf) produced in the glass electrode system varies linearly with $\mathrm{pH}$. This linear relationship is described by plotting the measured emf against the $\mathrm{pH}$ of different buffers. Sample $\mathrm{pH}$ was determined by extrapolation.

\subsection{Materials}

PH meter, conical flask, Balance, Funnel, Shaker, Distilled water, soft tissue paper, Samples, Buffer Solutions ( $\mathrm{pH} 4.0$, 10.0and $\mathrm{pH} 7.0$,)

\subsection{Procedure}

The $\mathrm{pH}$ meter is standardized with standard buffers of $\mathrm{pH} 4$, and 7 respectively. Before taking each reading electrode is washed with distilled water and then dried with soft tissue paper. The electrode is simply dipped in sample till the $\mathrm{pH}$ meter gives final reading that is considered being the $\mathrm{pH}$ value of sample.

\subsection{Total Soluble Solids}

Total soluble solids content expressed as Brix was determined by using refracto meter, (Atago 3810-Japan) as described by AOAC (1984) at temperature $(20$ C). Refractometer, Distilled water, Spatula, Soft tissue paper and Samples were used. Refractometer gives rapid and accurate ratio of TSS present in sample. TSS is expressed in terms of Brix. The representative sample is placed on dry refractometer prism and refractometer is calibrated and readings were taken directly. Refractometer prism is washed with distilled water and dried with soft tissue paper after each reading.

\subsection{Total Titratable Acidity}

Total titratable acidity of samples was determined by following standard AOAC (1984) method by titrating against strong alkali solution. Burrette stand, 50ml Burrette, Conical flasks, volumetric flasks, Filter cloth, Distilled water, Funnel, Graduated cylinder, 10-ml sample were used. $\mathrm{NaOH}(0.1 \mathrm{~N})$ 2-g pellets of $\mathrm{NaOH}$ are dissolved in $1000 \mathrm{ml}$ distilled water, The resulting solution will be $0.1 \mathrm{~N} \mathrm{NaOH}$ normal solution (Base) were used during analysis. 0.1g phenolphthalene is dissolved in $50 \mathrm{ml}$ distilled water and $50 \mathrm{ml}$ alcohol to prepare Phenolphthalene indicator. $5 \mathrm{~g}$ sample is taken in volumetric flask and the volume is made with distilled water up to $100 \mathrm{ml}$. Filter the sample if needed. The diluted sample $(10 \mathrm{ml})$ is taken in a conical flask and 2-3 drops of phenolphthalene indicator and titrated against $0.1 \mathrm{~N} \mathrm{NaOH}$ solution which is filled in a burrette. Continue titration till the solution persists pink color. Appearance of pink color is the end point and the color is persisted for 15-20 seconds. Finally the $\mathrm{ml}$ of $0.1 \mathrm{~N} \mathrm{NaOH}$ used is recorded for all the samples and acidity is calculated by 
using the following formula,

$$
\text { Acidity }=\text { F x T x 0.1N NaOH x } 100 \times 100 / \mathrm{L} \times \mathrm{M}
$$

Where, $\mathrm{F}$ is factor of acid (citric acid) which is equal to 0.0064 .

\subsection{Reducing Sugars}

AOAC (1984) recommends following procedure for the determination of reducing sugars present in samples. $50 \mathrm{ml}$ Burette, Stand, conical flask, volumetric flask, distilled water, filter cloth, 100ml-graduated cylinder, test tube holder, funnel, and $5 \mathrm{~g}$ sample was used. Fehling Solution A: $34 \mathrm{~g}$ $\mathrm{CuSO}_{4} .5 \mathrm{H}_{2} \mathrm{O}$ is dissolved in $500 \mathrm{ml}$ of distilled water. Fehling solution B: $173 \mathrm{~g}$ Sodium Potassium Tarter ate and $50 \mathrm{~g}$ of $\mathrm{NaOH}$ is dissolved in $500 \mathrm{ml}$ distilled water and as Indicator: Methylene Blue. Fruit grounded sample $(5 \mathrm{~g})$ is taken and diluted up to $100 \mathrm{ml}$ with distilled water. The burrette is filled with this solution. $5 \mathrm{ml}$ fehling A and $5 \mathrm{ml}$ fehling B with $10 \mathrm{ml}$ of distilled water is taken in conical flask and boiled, On boiling it was titrated against the sample solution from the burrette till color changes to dark brown or red. 2-3 drops of methylene blue is added as indicator till dark brown or red color persisted. The $\mathrm{ml}$ of sample is then recorded and reducing sugar percentage is calculated by using the following formula.

$\mathrm{Xml}$ of sample solution $=0.05 \mathrm{~g}$ of reducing sugar

$100 \mathrm{ml}$ of sample solution contains $=100 \times 0.05 / \mathrm{Xml}=\mathrm{Yg}$ of reducing sugar

This $100 \mathrm{ml}$ of sample solution was prepared from $5 \mathrm{~g}$ sample

So,

$5 \mathrm{~g}$ sample contains $=\mathrm{Yg}$ of reducing sugar

$\%$ Reducing sugar in sample $=$ Yg X $100 / 5$

\subsection{Ash Content}

Ash is the inorganic residue remaining after the complete oxidation of organic matter in foodstuff. AOAC (1990) recommends following procedure for determination of ash content. Balance precisian, china dishes, electrical muffle furnace, oven, spatula, desiccator, test tube holder, and $10 \mathrm{-g}$ sample was used during chemical analysis of samples. China dishes were taken and weighted properly and weight is noted down. 10-gm of sample is added in china dish. Then charred the sample or dry in oven at $70^{\circ} \mathrm{C}$ for $2-4$ hours. In temperature up to $100^{\circ} \mathrm{C}$ and left it for 24 hours. After 24 hours dry matter is obtained. The sample must be dried in oven till it gives constant weight of sample. After drying the sample 1-gm dry sample is taken in china dish and incarnated in muffle furnace at $550^{\circ} \mathrm{Cfor} 12-18$ hours. Turn off the muffle furnace after the required time and wait till the temperature inside furnace dropped to at least $250^{\circ} \mathrm{C}$. Door of muffle furnace is opened carefully to avoid losing ash that may be fluffy. Ash obtained is transferred in desicator for cooling. After cooling ash is weighted and calculated on the basis of following formula:

$$
\% \text { Ash }=\text { Initial Weight }- \text { Final weight / Initial weight x } 100
$$

\subsection{Moisture Content}

Sample was dried in the oven provided with opening for ventilation and maintained at 130c for 60 minutes. The loss in sample weight is expressed as percentage moisture. China dish, Desiccators, Silica granules, Rubber gloves were used. Perten laboratory mill 3100, Analytical Balance, Accuracy +/$0.0001 \mathrm{~g}$, Hot air oven was used. Clean moisture dishes were taken and dried in oven at 130c for 30 minutes. Moisture dishes were taken out and placed in desiccators and weighed soon after they reach at room temperature. $10 \mathrm{~g}$ of well-mixed sample was added to the each moisture dish and recorded the weight. Removed from scale and covered with lid.

Placed the moisture dish in oven uncovered for 60 minutes (60 minutes dry period Begin when oven temperature is usually 130c. Afterward removed the sample from oven and covered with lid. Place the sample in desiccators for cooling. Gloves were used for sample transfer room oven to the desiccators.

Weighed the sample till after reached at room temperature.

$$
\% \text { moisture }=\frac{w t \text { of original sample }- \text { wt of dried sample }}{\text { Wt of original sample }} \times 100
$$

\section{Result}

\subsection{Physico Chemical Analysis of Pomegranate}

Table 1. Total Soluble Solid Of Pomegranate.

\begin{tabular}{lllll}
\hline Varieties & Jalalabad & Bagrote & Jutal & Mean \\
\hline Sour & 11 & 11 & 11.5 & 11.1 \\
Sweet & 14 & 14 & 14.5 & 14.1 \\
Doom & 14.1 & 14.1 & 14.2 & 14.1 \\
\hline
\end{tabular}

3.2. Above Readings Is Mean of Three Replication

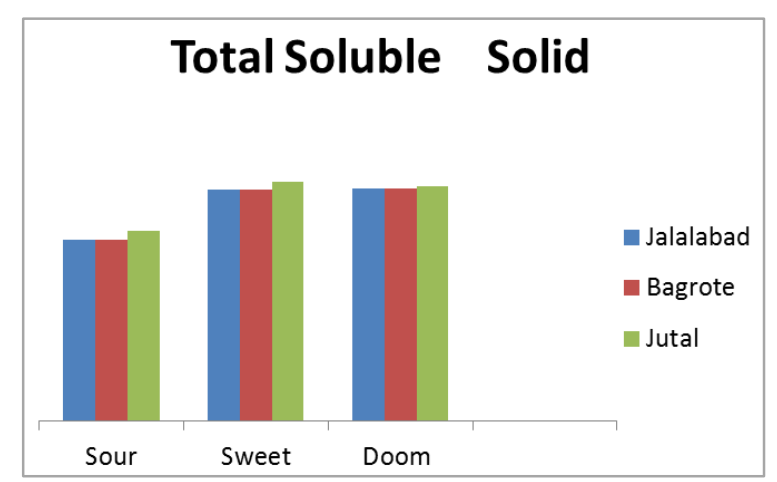

Figure 1. Total Soluble Solid of Pomegranate.

Table 2. pH of pomegranate.

\begin{tabular}{lllll}
\hline Varieties & Jalalabad & Bagrote & Jutal & Mean \\
\hline Sour & 2.5 & 2.6 & 2.4 & 2.5 \\
Sweet & 3.9 & 3.6 & 3.86 & 3.78 \\
Doom & 3.2 & 3.2 & 3.1 & 3.1 \\
\hline
\end{tabular}




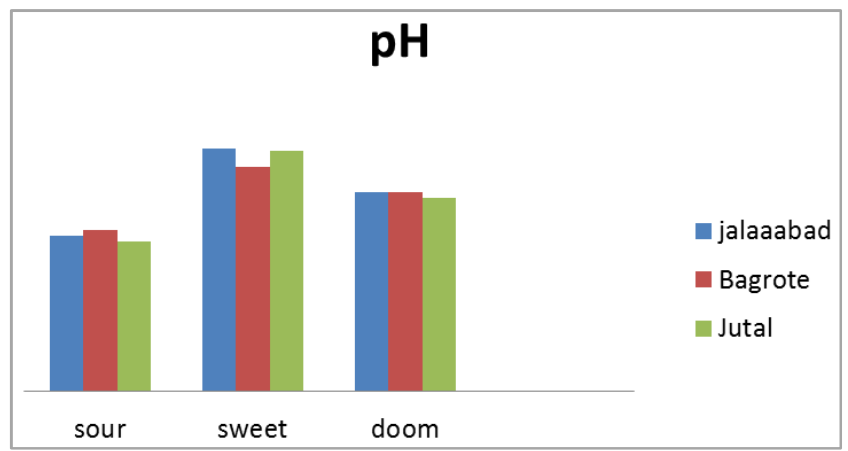

Figure 2. pH of pomegranate.

Table 3. Ttitratable Acidity in pomegranate.

\begin{tabular}{lllll}
\hline Varieties & Jalalabad & Bagrote & Jutal & Mean \\
\hline Sour & 0.867 & 0.879 & 0.885 & 0.876 \\
Sweet & 0.362 & 0.382 & 0.399 & 0.381 \\
Doom & 0.645 & 0.654 & 0.665 & 0.654 \\
\hline
\end{tabular}

\subsection{Above Readings Is Mean of Three Replication}

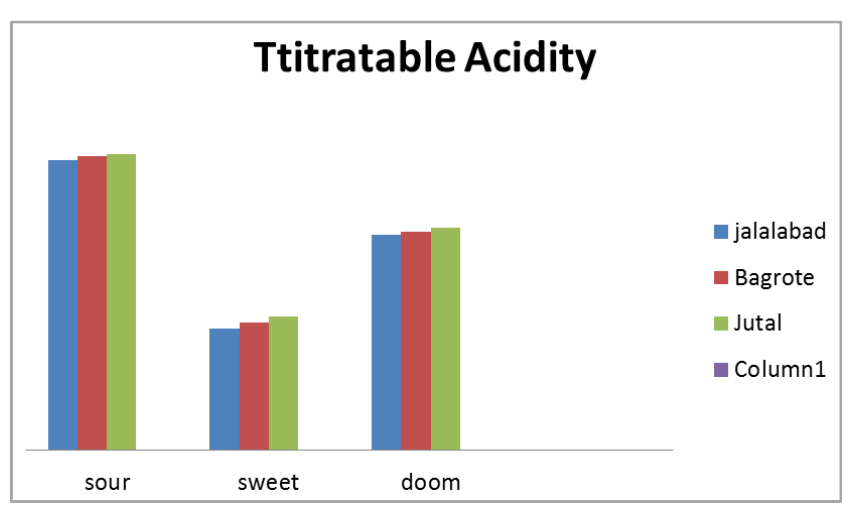

Figure 3. Ttitratable Acidity in pomegranate.

Table 4. Reducing sugar in Pomegranate Fruit.

\begin{tabular}{lllll}
\hline Varieties & Jalalabad & Bagrote & Jutal & Mean \\
\hline Sour & 07.00 & 7.18 & 7.27 & 7.15 \\
Sweet & 11.99 & 12.25 & 12.65 & 12.29 \\
Doom & 10.05 & 10.08 & 10.2 & 10.11 \\
\hline
\end{tabular}

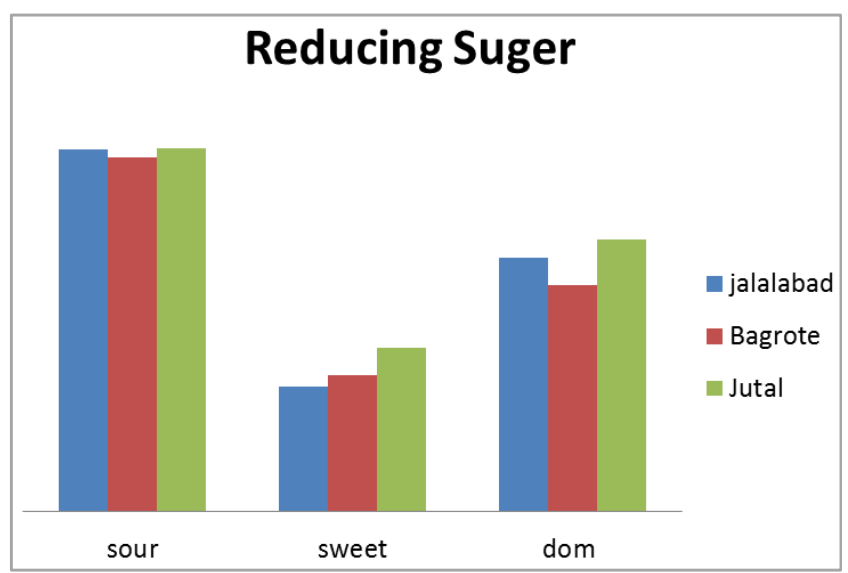

Figure 4. Reducing sugar in pomegranate fruit.
Table 5. Moisture in Pomegranate Fruit.

\begin{tabular}{lllll}
\hline Varieties & Jalalabad & Bagrote & Jutal & Mean \\
\hline Sour & 73.82 & 72.24 & 73.1 & 73.05 \\
Sweet & 77.5 & 76.3 & 77.2 & 77 \\
Doom & 75.3 & 74.6 & 74.2 & 74.83 \\
\hline
\end{tabular}

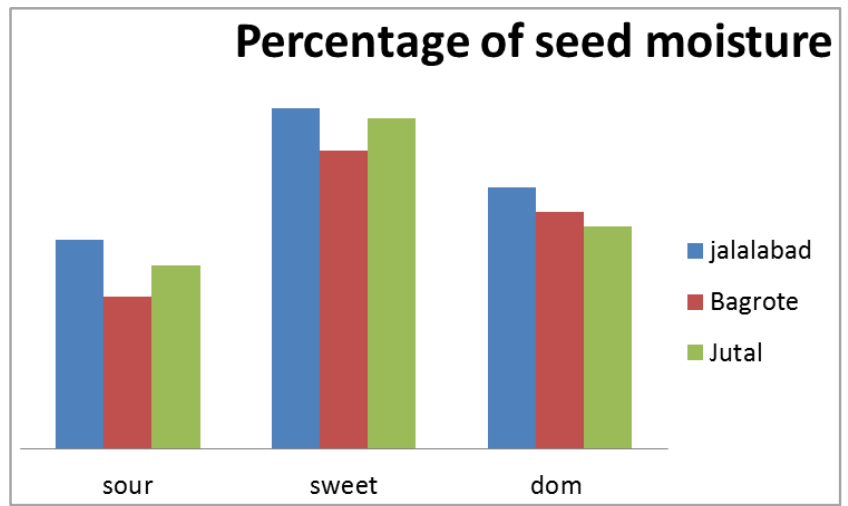

Figure 5. Percentage of seed moisture in pomegranate.

Table 6. Pecentage of seed Ash in pomegranate.

\begin{tabular}{lllll}
\hline varieties & Jalalabad & Bagrote & Jutal & Mean \\
\hline sour & 0.59 & 0.56 & 0.52 & 0.556 \\
sweet & 0.64 & 0.6 & 0.69 & 0.64 \\
Doom & 0.55 & 0.59 & 0.55 & 0.56 \\
\hline
\end{tabular}

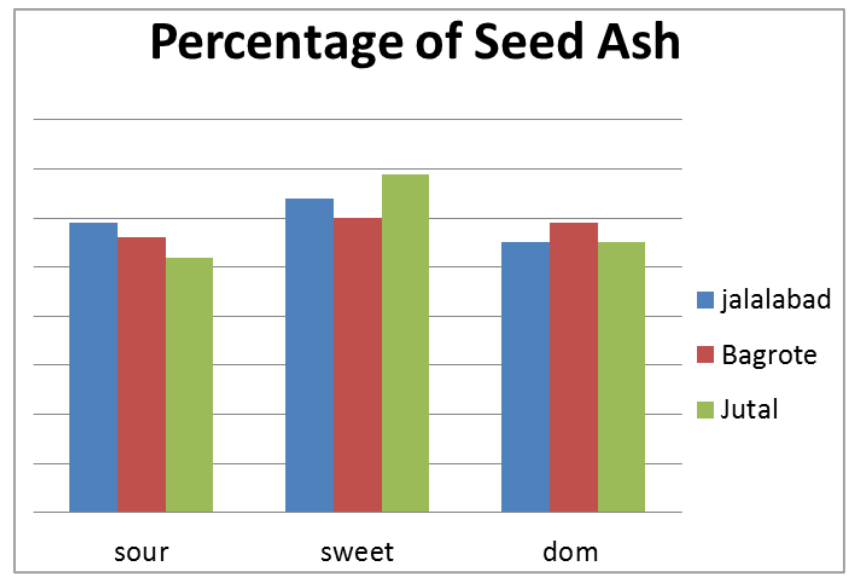

Figure 6. Percentage of seed ash in pomegranate.

\section{Discussion}

\subsection{Physico Chemical Analysis of Pomegranate}

The chemical composition of fruit differs depending on the cultivar, growing region, climate, maturity, cultural practice and storage conditions (Melgarejo et al., 2000; Nanda et al., 2001; Barzegaret al., 2004; Miguel et al., 2004b; Fadavi et al., 2005).

The results for total soluble solids, $\mathrm{pH}$, titrable acidity, and maturity index of the pomegranate from the different Localities.

Total soluble solids\%: In Jalalabad valley the highest total soluble solids content in $14{ }^{\circ}$ Brix (Sweet), 14.1 ${ }^{\circ}$ Brix (Doom), $11.0 \circ$ Brix (Sour). In Bagrote valley the highest total soluble solids content in $14.00^{\circ}$ Brix (Sweet), 14.1 ${ }^{\circ}$ Brix (Doom), 11.0 
${ }^{\circ}$ Brix (Sour). In Jutal valley the highest total soluble solids content in 14.5 ${ }^{\circ}$ Brix (Sweet), $14.2 \circ$ Brix (Doom), and $11.5 \circ$ Brix (Sour). Over all the Total soluble solid is high in Jutal because due to the clay soil as shown in Table 1. While our results were in agreement with values (10-16.5 ${ }^{\circ}$ Brix) reported by (Fadavi et al,. 2005).

The total soluble solids observed in the present study were found to be in typical range as reported by other researchers (Radunić, Mira, et al. 2015).

Acidity $\%$ :

Data in Table 3 show that, pomegranate cultivars Titratable Acidity \% in Jalalabad valley the highest are $0.36 \%$ (sweet), $0.64 \%$ (Doom), $0.86 \%$ (Sour). Acidity \% in Bagrote valley is highest $0.382 \%$ in (sweet), $0.654 \%$ in (Doom), and $0.87 \%$ in (Sour). Acidity \% in Jutal valley is highest $0.399 \%$ in (sweet), $0.665 \%$ in (Doom), and $0.885 \%$ in (Sour).

The minimum acidity of pomegranate juice is $0.35 \%$ which was reported by (Mustafa Ozgen et al., 2008).The titratable acidity content varied from 0.33 , similar results were also reported by Fadavi et al. (2005).

According to (Melgarejo, 1993), the predominant acid of this fruit is malic acid. In studies carried out with the Mollar variety quantities of malic and citric acid. The content of malic acid ranged between $0.143 \%$ and $0.249 \%$ and the citric acid between $0.147 \%$ and $0.4 \%$ (Sharms et al., 1997).

Reducing sugar: Data in Table 4: show that, in Jalalabad pomegranate juice reducing sugar content are $11.99 \%$ ( sweet), $10.05 \%$ ( Doom), $7.7 \%$ (Sour) and, in Bagrote pomegranate cultivars reducing sugar content are $12.25 \%$ ( sweet), $10.08 \%$ ( Doom), $7.18 \%$ (Sour).In Jutal pomegranate cultivars reducing sugar content are $12.65 \%$ ( sweet), $10.20 \%$ ( Doom), $7.27 \%$ (Sour).

Reducing sugar ranged $13.89 \%$ this finding is (Al-Kahtani and Saxena et al,. 1987)

Our results are in agreement with findings of a study carried out in Egypt (I.E. Abd El-Rhman, 2010).

$p H$ : Data in Table. 2 show that, in Jalalabad pomegranate cultivars $\mathrm{pH}$ are 3.92 in (sweet), 3.2 in (Doom), and 2.5 in (Sour). In Bagrote pomegranate cultivars $\mathrm{pH}$ are 3.68 in (sweet), 3.22 in (Doom), 2.6 in (Sour). InJutal pomegranate cultivars $\mathrm{pH}$ are 3.86 in (sweet), 3.11 in (Doom), and 2.45 in (Sour).

The $\mathrm{pH}$ ranged from 2.75 to 4.14 , the findings of this research are more than average (3.34) reported by Mustafa et al., 2008.

The $\mathrm{pH}$ values ranged between 3.16 and 4.09 the $\mathrm{pH}$ values obtained in the current study are greater than those reported by Cam et al. (2009) on pomegranate cultivars grown in Turkey.

The $\mathrm{pH}$ range $(2.75-4.14)$ is appeared as representative range as reported in different studies and the $\mathrm{pH}$ values recorded in in the current study were also observed in the same range (Radunić, Mira, et al. 2015).

\subsection{Physical Analysis of Pomegranate Fruit}

Seed Ash\%:

Data in Table 9: show that, in Jalalabad pomegranate cultivars seed Ash \% are $0.64 \%$ in (sweet), $0.55 \%$ in (Doom), and $0.59 \%$ in (Sour). In Bagrote pomegranate cultivars seed Ash $\%$ are $0.60 \%$ in (sweet), $0.59 \%$ in (Doom), and $0.56 \%$ in (Sour). In Jutal pomegranate cultivars seed Ash \% are 0.69\% in (sweet), $0.55 \%$ in (Doom), and $0.52 \%$ in (Sour).

Seed moisture \%:

Table 5: the seed moisture percentage of the studied in Jalalabad pomegranate cultivars $77.5 \%$ (Sweet), $75.3 \%$ (Doom), 73.82\% (Sour). The seed moisture percentage of the studied in Bagrote pomegranate cultivars 76.3\% (Sweet), 74.6\% (Doom), 72.24\% (Sour). The seed moisture percentage in Jutal pomegranate verities $77.2 \%$ (Sweet), 74.3\% (Doom) and $73.11 \%$ (Sour).

The moisture content of the seeds up to $81.53 \%$ was reported by Amit Parasahar (2010). Evaluations of various important components are also reported previously to highlight the important pomegranate characteristics (Zaouay Faten et al., 2012).

\section{Conclusion}

In the current study physico-chemical properties of pomegranate indigenous to Gilgit-baltistan were determined. The evaluated parameter includes the total soluble solids, acidity, reducing sugurs, $\mathrm{pH}$, seed ash and seed moisture. Significant difference in the physicochemical properties such as sugurs, soluble solids, seed moisture and $\mathrm{pH}$ were observed. This study is important in exploring the knowledge of indigenous plants and also increases the information of pomegranate associated properties in specified study region. Whereas, difference in physico-chemical characteristics of the indigenous pomegranate varieties showing the genetically diversity among the species of this Gilgit-baltistan (Rajasekar, Dhivyalakshmi, et al. 2102). Furthermore, such studies may help to the producers or companies for selecting the better indigenous pomegranate specie having better composition.

\section{References}

[1] AOAC. 1990, 1984. Official methods of analysis, association of analytical chemist. $\left(15^{\text {th }}\right.$ Ed) Virginia, 22201, Arlington, USA.

[2] Aviram M, Volkova N, Coleman R, Dreher M, Reddy MK, Ferreira D, Rosenblat M. 2008.Pomegranate phenolics from the peels, arils, and flowers are antiatherogenic: studies in vivo in atherosclerotic apolipoprotein e-deficient (E 0) mice and in vitro in cultured macrophages and lipoproteins. J. Agric Food Chem 56 (3).

[3] Biale, J. B., 1981. Respiration and ripening in fruitsretrospect and prospect. In J. Friend and M. J. Rhodes (Eds.), Recent advances in the biochemistry of fruits.

[4] Barone, E., T. Caruso, F. P. Marra and F. Sottile, 2001. Preliminary observations on some Sicilian pomegranate (Punicagranatum L.). Journal of American Pomological Society, 55(1):4-7.

[5] Gil, M. I., C. Garcia-Viguera, F. Artes and F. A. TomasBarberan, 1995. Changes in pomegranate juice pigmentation during ripening. Journal of the Science of Food and Agriculture, 5(68): 77-81. 
[6] Gil, M. I., F. A. Tomas-Barberan, B. Hess-Pierce, D. M. Holcroft and A.A. Kader, 2000. Antioxidant activity of pomegranate juice and its relationship with phenolic composition and processing. Journal of Agriculture and Food Chemistry, 48: 4581-4589.

[7] Hodgson, R. W., 1917. The pomegranate. Calif. Agric. Expt. Sta. Bul., 276: 163-192. Nagy, P., P. E. Shaw and W.F. Wordowski, 1990. Fruit of Tropical and Subtropical Origin. Florida Science Source, Florida, USA., pp: 328-347.

[8] Harde, H., W. Schumacher, F. Firbas and D. Deffer, 1970. Strasburg's Textbook of Botany. Chaucer, London. vegetables. London: Academic Press, pp: 1-39.

[9] Kumar, G. N. M., 1990. Pomegranate. In S. Nagy, P. E. Shaw, and W. F. Wardowski (Eds.), Fruits of tropical and subtropical origin Auburndale, FL: Ag Sciences, Inc., pp: 328-347.

[10] Radunić, Mira, Maja Jukić Špika, Smiljana Goreta Ban, Jelena Gadže, Juan Carlos Díaz-Pérez, and Dan MacLean. "Physical and chemical properties of pomegranate fruit accessions from Croatia." Food chemistry 177 (2015): 53-60.

[11] Rania, J., H. Ne'jib, M. Messaoud, M. Mohamed and T. Mokhtar, 2007. Characterization of Tunisian pomegranate (Punicagranatum). cultivars using amplified fragment length polymorphism analysis Scientia Horticulturae.

[12] Rajasekar, Dhivyalakshmi, Casimir C. Akoh, Karina G. Martino, and Daniel D. MacLean. "Physico-chemical characteristics of juice extracted by blender and mechanical press from pomegranate cultivars grown in Georgia." Food Chemistry 133, no. 4 (2012): 1383-1393.

[13] Vahis Akbarpour, Khodayar Hemmati and Mehdi Sharifani. j. Agric. environ. Sci., 6(4): 411-416, 2009.

[14] Zaouay, Faten, Pedro Mena, Cristina Garcia-Viguera, and Messaoud Mars. "Antioxidant activity and physico-chemical properties of Tunisian grown pomegranate (Punica granatum L.) cultivars." Industrial Crops and Products 40 (2012): 81-89. 